\title{
Are We Meeting SRM's 1978 Long-range Objectives
}

By Daniel L. Merkel, President 1979

The February 1979 issue of Rangelands 1(1) included "eight long-range objectives" for the Society as part of my "President's Notes". I have been asked to describe how I perceive these objectives today to answer, "Are we (SRM) meeting them?" The eight objectives included greater assistance in the development of rangeland policy; increase the understanding of the importance of rangelands in food and fiber production, environmental protection and supplying people's needs; improve the professional level of rangeland specialists and institutions; provide an improved media for technology transfer and a forum for the exchange of range information; further develop our leadership in international rangeland management; and, encourage a sound rangeland research program.

These objectives were developed by the 1978 SRM officers and directors; and, were a basis for the Society's 1979 and 1980 programs of work. These objectives were important to the rangeland resource, profession and Society in 1978 and remain so today. This was the first and one of the few times the president and board of director's goals for SRM have been published in Rangelands.

To determine how well SRM is meeting these objectives, one must remember the wide range of interests and priorities among the SRM members. Also, the Society is like an area of rangeland; it responds to the kind of management it receives. Over the last twenty-five years we had presidents, boards and executive vice presidents with varied interests, priorities, management styles and levels of commitment leading the Society. As a result, we made good progress on several objectives some years, while lacking advancement on others. We failed to maintain steady long term progress in meeting most of the eight objectives. In some we are in better positions than in 1978; in others we fell behind.

Our progress in meeting objective 1 (Provide technical assistance in the development of rangeland policy.) has been disappointing. Our efforts to influence policy are below the level they were in the 1970s and 1980s. During many of those years, SRM had important input into rangeland legislation, policy and regulations. Until the favorable advances of the last few years, the Society missed these opportunities too often.

The second objective (Further public awareness on an international basis in the function rangeland performs in the productions of food and fiber, protection of the environment, and meeting man's needs.); and, third (Further the appreciation that rangelands perform in meeting the social, cultural, and political needs of people.) are closely linked. Much has been done by SRM and many others, like the Australian Rangeland Society and International Rangeland Congresses, since 1978 on these objectives. SRM and their partners must continue this effort and increase programs to better direct this growing public awareness and appreciation for rangelands to encourage their long term health. With current technology, the Society has the best opportunity ever to advance an improved understanding of rangelands through web sites and other mass communications. The Society has an opportunity to provide leadership working with other groups and organizations to develop and conduct these needed programs.

We should not leave objectives 2 and 3 without calling attention to SRM's interest 25 years ago in "protection of the environment", and "the social, cultural and political needs of people". We have and should remain interested in all rangeland uses and resources; but, continue to concentrate on sustainable rangelands as a major objective.

SRM has a mixed record in meeting objective 4 (Provide a basis to increase and improve the professional level of those individuals and institutions associated with the sciences and management of rangelands.) The Society's certified range consultant and certified professionals in rangeland management programs provide a basis to improve the 
professional status of many individuals involved in rangeland guidance and/or management; and, increase the confidence of that work by the public. These programs, also, bring more attention to the continuing education value of SRM meetings, tours, workshops, etc. The last SRM meeting, however, highlighted the growing concern about the decline of support for and participation in rangeland institutions, like university range management departments. Although there are many reasons for this decline, it reflects SRM's failure to meet this part of objective 4.

Our effort to accomplish objective 5 (Through programs provide media for technology transfer for all those interested in the science and application of range science information.) and 7 (Take leadership in providing a forum for the dissemination and exchange of range science information.) has maintained a stable trend. The combination of the Journal of Range Management, Rangelands and The Trail Boss News publications continue to provide a wide variety of information for all levels of interest. The percent of SRM members attending the annual meeting is higher than most, perhaps all, similar professional societies, and this percentage has increased during the last 25 years. The Society's high school and university student programs are the envy of many resource organizations and the pride of most SRM members. Since 1978 these programs have been improved and realized a growing student participation.

SRM's rangeland technology transfer and information programs, however, have lost some of the influence they had in the late 1960s to early 1980s. At that time, the Society was recognized for its publication and distribution of books on range science and history, which were used by the public and in classrooms. An Old West Regional Commission contract with SRM during part of this time provided funding for hosting rangeland meetings, tours and workshops. Those funds also, made it possible for SRM to develop several rangeland films which have been widely used by many groups.

The Society has made good progress in meeting objective 6 (Develop SRM as a recognized body serving a lead role in management of the world's rangelands.). The first International Rangeland Congress was hosted by SRM at Denver in 1978. The continuing success of the Congress has provid- ed a forum for individuals, organizations and institutions interested in the world's rangelands to share information, research and experiences to the benefit of all. SRM should, also, take pride in the increased number of articles in our publications about range issues in countries around the world. Because of reductions in natural resource budgets, the Society and its members have been limited in their opportunity to assist on the ground in improving range conditions at home or abroad.

SRM has done better in meeting the goals of objective 8 (Serve to encourage a sound basic and applied research program aimed at the expansion of rangeland management knowledge.) than many expected considering the reduced funds and research positions. There is reason to believe SRM could have done more to meet this objective if we had been more aggressive and politically astute in working with the concerned governmental representatives and agencies.

The same "President's Notes" column that contained these objectives included the following about SRM research activities. "The Society's Research Committee has worked closely with several members of Congress to develop a rangeland research bill which is appearing in Rangelands". Had we continued to work with Congress and others to encourage full funding of this and similar legislation during the past 25 years, our accomplishments on this objective may have improved.

In summary, SRM has worked towards meeting all objectives with a mixed degree of success.

It is doubtful any of the 1978 Society officers or directors are fully pleased with the progress we have made on any of these. SRM, however, accomplished many things in the last 25 years that are not included in these objectives. For example, we have a stronger financial base than in 1979. The Society and many of its members have provided hundreds of scholarships to improve students' interest in and understanding of rangelands. Thousands of lasting friendships and some marriages developed from participation in the SRM. And, yes, we provided much of the leadership to make many of the World's rangelands better than they were in 1978. We must continue to work together to do even more to meet these and other goals in the next quarter century than we did in the last. 